\title{
Don't just look at the surface: when mucosa tells more than the skin
}

\author{
Andrea Trombetta (D) ,' Laura De Nardi (D) , ${ }^{1}$ Egidio Barbi, ${ }^{1,2}$ Valentina Declich, ${ }^{3}$ \\ Roberto Dall'Amico ${ }^{3}$
}

A 13-year-old boy was admitted for a 4-day history of fever, malaise, sore throat and cough, treated with amoxicillin for 2 days. Physical examination revealed sparse targetoid cutaneous lesions, stomatitis with vesicles, blisters and mild conjunctival hyperaemia (figure 1). Blood tests showed an increase in erythrocyte sedimentation rate $(92 \mathrm{~mm} /$ hour; normal value $<20 \mathrm{~mm} /$ hour) and in $\mathrm{C}$ reactive protein level $(4.8 \mathrm{mg} / \mathrm{dL}$; normal value $<0.5 \mathrm{mg} / \mathrm{dL})$, while white cell count was $12.7 \times 10^{\wedge} 9 / \mathrm{L}$ (7lymphocytes $7.2 \times$ $10^{\wedge} 9 / \mathrm{L}$, neutrophils $3.32 \times 10^{\wedge} 9 / \mathrm{L}$ ). In the following days, he developed preputial ulceration with painful micturition.

\section{QUESTION 1}

What is the most likely diagnosis?

A. Erythema multiforme (EM) major.

B. Herpetic gingivostomatitis.

C. Antibiotic-induced Stevens-Johnson syndrome (SJS).

D. Mycoplasma pneumoniae-induced rash and mucositis (MIRM).

\section{QUESTION 2}

What test could confirm this diagnosis?
A. Nasopharyngeal swab and virus PCR.
B. Skin biopsy.
C. Repeated serological assay and PCR for Mycoplasma pneumoniae (MP).
D. None of the mentioned.

\section{QUESTION 3}

What is the mainstay of management?
A. IV corticosteroids
B. IV Ig
C. Supportive and topical therapy
D.Antibiotic therapy

Answers can be found on page 2 .

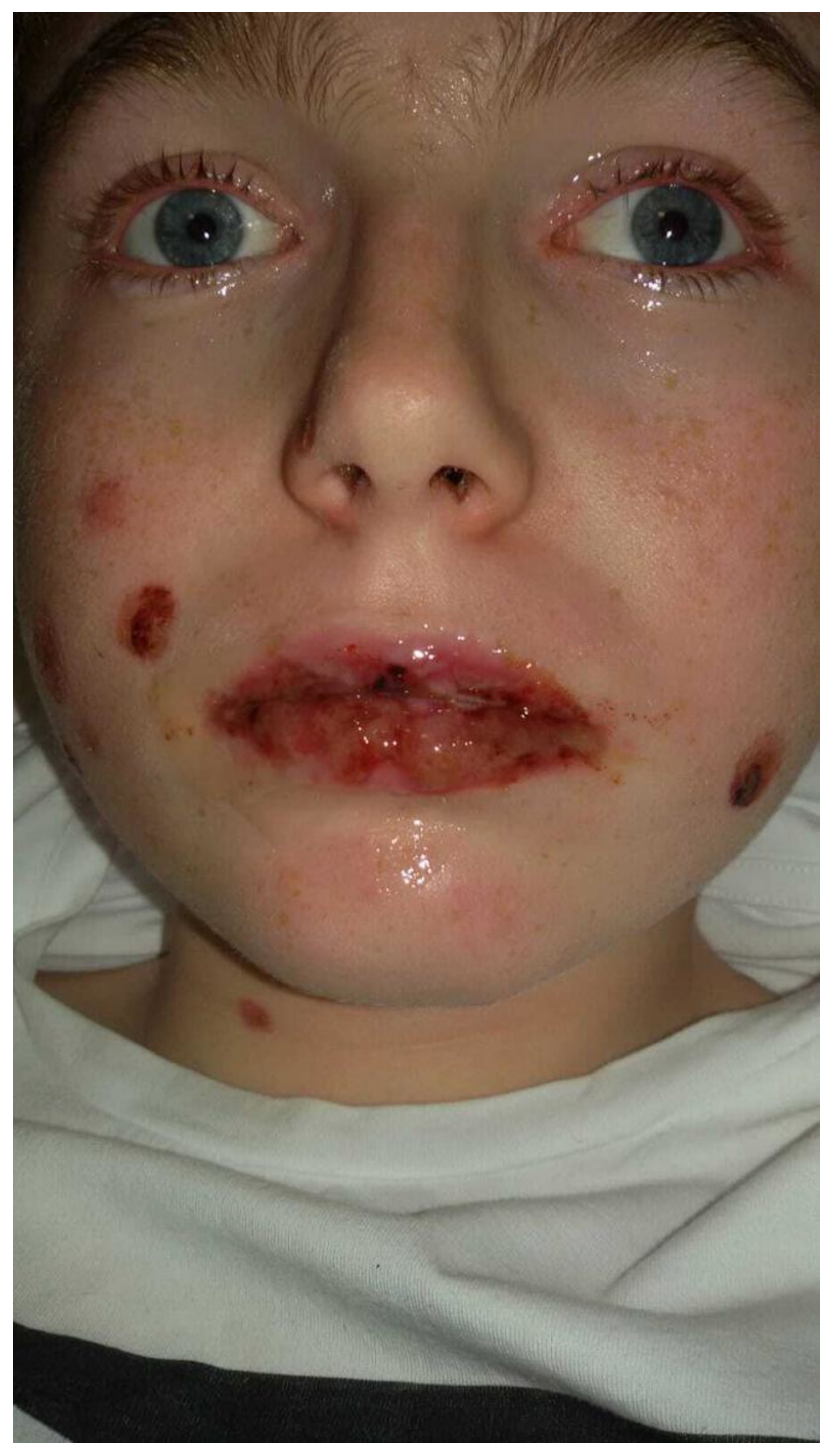

Figure 1 Vesicular oral lesions and conjunctivitis. 


\section{ANSWERS TO THE QUESTIONS ON PAGE 1 Answer to question 1: D}

MIRM is characterised by mucositis, possibly but not necessarily associated with sparse cutaneous involvement, which occurs after an MP infection.

Canavan et $a l^{1}$ considered this condition a separate entity from SJS due to its distinctive epidemiology, morphology, pathophysiology and disease outcomes. For this reason, specific diagnostic criteria have been proposed (table 1). From an epidemiological point of view, patients with MIRM are usually young and predominantly male. ${ }^{1}$ The incidence of MIRM is closely related to the spread of MP, whereas around $25 \%$ of patients with this infection may have mucocutaneous eruption. ${ }^{2}$ Clinically, these subjects usually present prodromal respiratory symptoms, followed after 1 week by mucocutaneous rash. In particular, MIRM affects the oral mucosa in 94\% of cases and often the urogenital region. ${ }^{1}$ These clinical features can help doctors distinguish MIRM from EM major, usually and predominantly characterised by skin involvement with acral targetoid lesions and minimal or absent mucosal implication. ${ }^{1}$

This patient developed a lower degree of skin involvement than SJS, along with vesiculobullous and significant erosive mucosal eruptions that also involved the urogenital region, as part of a respiratory tract infection. The absence of widespread epidermal necrosis, and the extensive and centrally distributed lesions, along with the type of exposure to drug which is not causative of SJS, further helped to rule out a drug-induced reaction. Finally, a diagnosis of toxic epidermal necrolysis was unlikely due to the absence of extensive cutaneous detachment.

Herpetic gingivostomatitis was also improbable due to multiorgan involvement. Nevertheless, in the setting of a differential diagnosis, a viral culture and a PCR for herpes simplex virus (HSV) should always be considered to rule out a herpetic infection, which is the main immunological trigger for EM major and can lead to potential complications in immunocompromised patients.

A differential diagnosis is relevant not only due to the different treatment options and patient education

\begin{tabular}{ll}
$\begin{array}{l}\text { Table } 1 \text { Proposed diagnostic criteria for classic cases of } \\
\text { Mycoplasma pneumoniae-induced rash and mucositis }\end{array}$ \\
\begin{tabular}{ll} 
Mucocutaneous eruption & Involvement of $\leq 10 \%$ body surface area \\
\hline $\begin{array}{l}\text { Number of mucosal sites involved } \\
\text { Few vesiculobullous lesions, or }\end{array}$ & Yes \\
$\begin{array}{l}\text { scattered, atypical } \\
\text { Targetoid lesions }\end{array}$ & \pm \\
$\begin{array}{l}\text { Clinical evidence of atypical } \\
\text { pneumonia }\end{array}$ & Fever, cough and auscultatory findings \\
$\begin{array}{l}\text { Laboratory evidence of atypical } \\
\text { pneumonia }\end{array}$ & $\begin{array}{l}\text { Increase in Mycoplasma pneumoniae } \\
\text { (MP) IgM antibodies, MP in } \\
\text { oropharyngeal or bullae cultures or PCR, } \\
\text { and/or serial cold agglutinins }\end{array}$ \\
\hline
\end{tabular} \\
\hline
\end{tabular}

but also to predict the course of the disease, which is usually milder compared with EM major ${ }^{3}$ and SJS, ${ }^{4}$ with an overall good prognosis and rapid recovery.

\section{Answer to question 2: D}

Laboratory tests usually show mild leucocytosis, with an increase in the values of inflammatory markers. Since most MIRM lesions are non-bullous exanthematous, ${ }^{5}$ a skin biopsy should be performed in the case of large, isolated bullous skin lesions, in differential diagnosis with autoimmune conditions such as linear IgA bullous dermatitis, bullous pemphigoid and pemphigoid vulgaris. ${ }^{6}$

Real-time PCR and serological assays have limited value in diagnosing an MP infection. ${ }^{5}$ The IgM assay has temporary sensitivity and specificity with poor positive and negative predictive values. ${ }^{7}$ Real-time PCR results depend on the type of samples tested, with a different sensitivity, which is never $100 \%,{ }^{8}$ and which remain positive until 4 months after the infection. Since MP antibodies can be detected several months after the infection, ${ }^{2}$ diagnosis without documentation of titre increase in paired sera can be misleading because it may include a recent but not the current infection. In this patient, with a positive serological assay with positivity for both IgM and PCR, the diagnosis and subsequent treatment were based mainly on clinical findings highly suggestive of MIRM.

\section{Answer to question 3: C}

MIRM treatment is directed to pain management, mucosal and skin care, and localised care in case of ocular and urogenital involvement, depending on the severity and extension of the lesions. For oral lesions, saline-soaked gauze can be applied several times a day to reduce pain and prevent accumulation of thick crust on the lips, while multiple daily applications of ocular lubricants are indicated for mild conjunctivitis, and topical triamcinolone ointment can be used for localised urogenital involvement . Daily assessment of fluid balance should likewise be given in order to establish the current fluid balance in case of intravenous replacement in severely affected patients and to avoid overhydration and resultant hyponatraemia. ${ }^{9}$ Similarly, great attention should be given to appropriate nutrition during the acute phase, including use of oral or nasogastric/nasojejunal feeding, depending on the severity of mucosal impairment. ${ }^{9}$

Although antibiotic utility to limit the duration and severity of the disease is debated, ${ }^{10}$ an empirical antibiotic therapy is often used in patients with clinical, laboratory or radiographic evidence of MP pneumonia.

\section{Patient outcome}

The patient was treated with topical steroid ointment for ocular and urogenital involvement. He fully recovered in 2 weeks. 
Andrea Trombetta $\odot{ }^{1}$, Laura De Nardi $\odot,{ }^{1}$ Egidio Barbi, ${ }^{1,2}$ Valentina Declich, ${ }^{3}$ Roberto Dall'Amico ${ }^{3}$

${ }^{1}$ Department of Medicine, Surgery and Health Sciences, University of Trieste, Trieste, Italy

${ }^{2}$ Department of Pediatrics, Institute for Maternal and Child Health IRCCS 'Burlo Garofolo', Trieste, Italy

${ }^{3}$ Department of Pediatrics, AAS 5 Ospedale 'Santa Maria degli Angeli', Pordenone, Friuli-Venezia Giulia, Italy

Correspondence to Dr Laura De Nardi, Department of Medicine, Surgery and Health Sciences, University of Trieste, Trieste 34127, Italy; laura.denardi1993@ gmail.com

Contributors AT and LDN wrote the first draft of the manuscript. RDA and VD clinically followed the patient. EB and RDA made revisions to the manuscript.

Funding The authors have not declared a specific grant for this research from any funding agency in the public, commercial or not-for-profit sectors.

Competing interests None declared.

Patient consent for publication Parental/guardian consent obtained.

Provenance and peer review Not commissioned; externally peer reviewed.

\section{(2) \\ OPEN ACCESS}

Open access This is an open access article distributed in accordance with the Creative Commons Attribution Non Commercial (CC BY-NC 4.0) license, which permits others to distribute, remix, adapt, build upon this work noncommercially, and license their derivative works on different terms, provided the original work is properly cited, appropriate credit is given, any changes made indicated, and the use is non-commercial. See: http://creativecommons.org/ licenses/by-nc/4.01.

(C) Author(s) (or their employer(s)) 2021. Re-use permitted under CC BY-NC. No commercial re-use. See rights and permissions. Published by BMJ.

\section{Check for updates}

To cite Trombetta A, De Nardi L, Barbi E, et al. Arch Dis Child Educ Pract Ed Epub ahead of print: [please include Day Month Year]. doi:10.1136/ archdischild-2020-319195

Received 18 March 2020

Accepted 30 December 2020

Arch Dis Child Educ Pract Ed 2021;:1-3. doi:10.1136/edpract-2020-319195

\section{ORCID iDs}

Andrea Trombetta http://orcid.org/0000-0003-2092-3067

Laura De Nardi http://orcid.org/0000-0002-8141-3389

\section{REFERENCES}

1 Canavan TN, Mathes EF, Frieden I, et al. Mycoplasma pneumoniae-induced rash and mucositis as a syndrome distinct from Stevens-Johnson syndrome and erythema multiforme: a systematic review. J Am Acad Dermatol 2015;72:239-45.

2 Waites KB, Talkington DF. Mycoplasma pneumoniae and its role as a human pathogen. Clin Microbiol Rev 2004;17:697728.

3 Schalock PC, Dinulos JGH, Pace N, et al. Erythema multiforme due to Mycoplasma pneumoniae infection in two children. Pediatr Dermatol 2006;23:546-55.

4 Wetter DA, Camilleri MJ. Clinical, etiologic, and histopathologic features of Stevens-Johnson syndrome during an 8-year period at Mayo clinic. Mayo Clin Proc 2010;85:1318.

5 Narita M. Pathogenesis of extrapulmonary manifestations of Mycoplasma pneumoniae infection with special reference to pneumonia. J Infect Chemother 2010;16:162-9.

6 Yeh SW, Ahmed B, Sami N, et al. Blistering disorders: diagnosis and treatment. Dermatol Ther 2003;16:214-23.

7 Chang H-Y, Chang L-Y, Shao P-L, et al. Comparison of realtime polymerase chain reaction and serological tests for the confirmation of Mycoplasma pneumoniae infection in children with clinical diagnosis of atypical pneumonia. J Microbiol Immunol Infect 2014;47:137-44.

8 Räty R, Rönkkö E, Kleemola M. Sample type is crucial to the diagnosis of Mycoplasma pneumoniae pneumonia by PCR. $J$ Med Microbiol 2005;54:287-91.

9 McPherson T, Exton LS, Biswas S, et al. British association of dermatologists' guidelines for the management of StevensJohnson syndrome/toxic epidermal necrolysis in children and young people, 2018. Br J Dermatol 2019;181:37-54.

10 Olson D, Abbott J, Lin C, et al. Characterization of children with recurrent episodes of Stevens Johnson syndrome. J Pediatric Infect Dis Soc 2017;6:e140-3. 